Penerapan Model Pembelajaran....(Nurma)

\title{
PENERAPAN MODEL PEMBELAJARAN KOOPERATIF TIPE THINK PAIR SHARE DALAM MENINGKATKAN HASIL BELAJAR IPS SISWA SMP NEGERI 2 PALEMBANG
}

\author{
Oleh: Nurma \\ Email: rosmalah@gmail.com \\ (Guru SMP Negeri 2 Palembang)
}

\begin{abstract}
Abstrak
Penelitian ini bertujuan untuk mengetahui bagaimana hasil belajar peserta didik setelah diterapkan model pembelajaran kooperatif tipe Think Pair share pada mata pelajaran IPS Kelas VII.8 SMP Negeri 2 Palembang. Penelitian ini adalah penelitian tindakan kelas (classroom action research). Subyek penelitian ini peserta didik Kelas VII.8 dengan jumlah 32 peserta didik. Prosedur penelitian terdiri dari perencanaan, pelaksanaan, pengamatan, dan refleksi. Teknik pengumpulan data yang digunakan dalam penelitian berupa hasil tes formatif, lembar observasi kegiatan belajar mengajar. Dari hasil analis didapatkan bahwa hasil belajar peserta didik mengalami peningkatan dari pra siklus sampai siklus II yaitu, pra siklus (34.38\%), siklus I (56.25\%), dan siklus II (90.63\%). Kesimpulan dari penelitian ini adalah Penerapan model pembelajaran kooperatif tipe Think Pair share dalam meningkatkan hasil belajar IPS pada siswa kelas VII.8 SMP Negeri 2 Palembang dapat berpengaruh positif terhadap hasil belajar peserta didik SMP Negeri 2 Palembang serta model pembelajaran ini dapat digunakan sebagai salah satu alternatif pembelajaran IPS.
\end{abstract}

Kata Kunci: Hasil Belajar Sejarah, Model Think Pair Share

\section{APPLICATION OF THE THINK PAIR SHARE TYPE COOPERATIVE LEARNING MODEL IN IMPROVING IPS LEARNING OUTCOMES STUDENTS SMP NEGERI 2 PALEMBANG}

\begin{abstract}
This study aims to determine how the learning outcomes of students after implementing the Think Pair share type of cooperative learning model in social studies class VII.8 SMP Negeri 2 Palembang. This study uses action research (classroom action research). The subjects of this study were students of Class VII.8 with a total of 32 students. The research procedure consisted of planning, implementing, observing, and reflecting. The data collection techniques used in the study were formative test results, observation sheets for teaching and learning activities. From the results of the analysis, it was found that the learning outcomes of students had increased from pre cycle to cycle II, namely, pre cycle (34.38\%), cycle I (56.25\%), and cycle II (90.63\%). The conclusion of this study is the application of the cooperative learning model type Think Pair share in improving social studies learning outcomes in class VII.8 students of SMP Negeri 2 Palembang can have a positive effect on student learning outcomes of SMP
\end{abstract}


Negeri 2 Palembang and this learning model can be used as an alternative. social studies learning.

Keywords: Learning Outcomes History, Think Pair Share Methods.

\section{A. PENDAHULUAN}

IPS merupakan salah satu mata pelajaran yang diberikan mulai dari SD/MI/SDLB sampai SMP/MTS/SMPLB. IPS mengkaji seperangkat isu sosial. Pada jenjang SD/MI mata pelajaran IPS memuat geografi, sejarah, sosiologi dan ekonomi. Melalui pembelajaran IPS, peserta didik diarahkan untuk dapat menjadi warga negara Indoensia yang demokrasi dan bertanggung jawab, serta warga dunia yang cinta damai.

Trianto (2010, p.171) mengemukakan IPS merupakan integrasi dari berbagai cabang ilmu-ilmu sosial, seperti sosiologi, sejarah, geografi, ekonomi, politik, hukum dan budaya yang dirumuskan atas dasar kenyataan dan fenomena sosial dan diwujudkan dalam suatu pendekataan interdisipliner dari aspek dan cabang ilmu-ilmu sosial. IPS merupakan bagian dari kurikulum sekolah yang diturunkan dari isi materi cabang-cabang ilmu sosial.

Somantri (2001, p.92) menyatakan bahwa Pendidikan IPS di sekolah (dasar dan menengah) merupakan pengintegrasian dari berbagai disiplin ilmu sosial dan humaniora, serta kegiatan dasar manusia yang diorganisasikan, disajikan secara ilmiah dan pedagogis untuk tujuan pendidikan. Pendidikan IPS untuk sekolah disajikan terpadu dengan mengintegrasikan beberapa disiplin ilmu yang ditujukan untuk kepentingan pendidikan. Keterpaduan berbagai disiplin ilmu ini siswa diharapkan mampu mencapai tujuan dari pendidikan itu sendiri.

Guru merupakan faktor yang sangat dominan dan paling penting dalam pendidikan formal pada umumnya karena bagi siswa guru sering dijadikan tokoh teladan bahkan menjadi tokoh identifikasi diri. Di sekolah guru merupakan unsur yang sangat mempengaruhi tercapainya tujuan pendidikan selain unsur murid dan fasilitas lainnya. Keberhasilan penyelenggaraan pendidikan sangat ditentukan kesiapan guru dalam mempersiapkan peserta didiknya melalui kegiatan belajar mengajar. Namun demikian posisi strategis guru untuk meningkatkan mutu hasil 
Penerapan Model Pembelajaran....(Nurma)

pendidikan sangat dipengaruhi oleh kemampuan profesional guru dan mutu kinerjanya.

Guru dituntut memiliki kinerja yang mampu memberikan dan merealisasikan harapan dan keinginan semua pihak terutama pihak sekolah menengah pertama yang telah mempercayai sekolah dan guru dalam membina anak didik. Dalam meraih mutu pendidikan yang baik sangat dipengaruhi oleh kinerja guru dalam melaksanakan tugasnya sehingga kinerja guru menjadi tuntutan penting untuk mencapai keberhasilan pendidikan. Secara umum mutu pendidikan yang baik menjadi tolok ukur bagi keberhasilan kinerja yang ditunjukkan guru.

Berdasarkan temuan guru hasil belajar ulangan harian mata pelajaran IPS di kelas VII.8 SMP Negeri 2 Palembang di Jl. Akbp H. Moh. Amin No.42, 24 Ilir, Kec. Bukit Kecil, Kota Palembang, Sumatera Selatan mendpapatkan nilai hasil belajar yang belum memenuhi harapan ketuntasan belajar siswa secara klasikal. Guru mata pelajaran IPS menetapkan ketuntasan siswa secara klasikal adalah $85 \%$. Setelah guru merekap hasil ulangan belajar IPS ditemukan dari 32 Siswa yang mengikuti ulangan harian hanya terdapat 20 siswa belum mampu melewati ketuntasan KKM (>70). Kemudian siswa yang bisa melampaui ketuntasan KKM hanya 12 siswa. Terdapat lebih dari setengah jumlah siswa kelas VII.8 yang belum tuntas yakni 20 siswa dengan persentase $62.50 \%$. Sedangkan persentase siswa yang tuntas adalah $37.50 \%$, masih jauh dari ketuntasan siswa secara klasikal yakni $85 \%$.

Melihat dari hasil belajar yang rendah tersebut, maka peneliti menemukan penyebab dari rendah nya hasil belajar IPS kelas VIII.8 SMP Negeri 2 Palembang. Adapun penyebab dari rendahnya antara lain: Siswa kurang berminat dalam mengikuti proses pembelajaran. Siswa kurang aktif dalam bertanya jika ada materi yang sulit. Guru masih mengajar dengan cara ceramah dan kurang melibatkan siswa dalam proses pembelajaran.

Maka dari itu perlu nya perbaikan dari guru sehingga proses pembelajaran bisa meningkat dari hasil belajar sebelumnya. Salah satu cara yang akan dipilih oleh guru peneliti dalam meningkatkan hasil belajar adalah memilih model 
pembelajaran kooperatif tipe Think Pair Share. Model pembelajaran kooperatif tipe Think Pair Share cocok dengan karakter siswa SMP Negeri 2 Palembang kelas VII.8 yang senang bekomunikasi dengan siswa yang lain. Berdasarkan latar belakang tersebut maka yang menjadi rumusan masalah dalam penelitian ini adalah apakah penerapan model pembelajaran kooperatif tipe Think Pair share dalam meningkatkan hasil belajar IPS pada siswa kelas VII.8 SMP Negeri 2 Palembang.

Model pembelajaran kooperatif (Cooperative Learning) merupakan salah satu model pembelajaran yang mendukung pembelajaran kontekstual. Sistem pengajaran Cooperative Learning dapat didefinisikan sebagai sistem kerja/ belajar kelompok yang terstruktur. Roger dan David dalam Lie (2005, p.31) mengatakan bahwa tidak semua kerja kelompok bisa dianggap cooperative learning. Untuk mencapai hasil yang maksimal, lima unsur model pembelajaran gotong royong harus diterapkan, lima unsur tersebut adalah saling ketergantungan positif, tanggung jawab perseorangan, tatap muka, komunikasi antar anggota, dan evaluasi proses kelompok.

Senada dengan pendapat Roger dan David, Slavin dalam Solihatin (2008, p.4) menyatakan bahwa cooperative learning adalah suatu model pembelajaran yang mana dalam pembelajaran tersebut siswa belajar dan bekerja sama dalam kelompok-kelompok kecil secara kolaboratif yang anggota dari kelompok tersebut terdiri dari 4 sampai 6 orang, dengan struktur kelompok bersifat heterogen. Rumusan lain tentang pembelajaran kooperatif dikemukakan oleh Sugiyanto (2010, p.37) menyatakan bahwa pembelajaran kooperatif (Cooperative learning) adalah pendekatan pembelajaran yang berfokus pada penggunaan kelompok kecil siswa untuk bekerjasama dalam memaksimalkan kondisi belajar untuk mencapai tujuan belajar.

Strategi TPS atau berpikir berpasangan berbagi dikemukakan oleh Trianto (2011, p.61) bahwa TPS adalah merupakan jenis pembelajaran kooperatif yang dirancang untuk mempengaruhi pola interaksi siswa. Strategi think-pair-share ini berkembang dari penelitian belajar kooperatif dan waktu tunggu. 
Penerapan Model Pembelajaran....(Nurma)

Pengertian TPS juga dikemukakan oleh Lie (2005, p.57) menyatakan bahwa, Think-Pairs-Share adalah pembelajaran yang memberi siswa kesempatan untuk bekerja sendiri dan bekerjasama dengan orang lain. Sedangkan Mulyatiningsih (2011, p.233) juga mengemukakan bahwa: TPS merupakan metode pembelajaran yang dilakukan dengan cara sharing pendapat antar siswa. Metode ini dapat digunakan sebagai umpan balik materi yang diajarkan guru. Pada awal pembelajaran, guru menyampaikan materi pelajaran seperti biasa. Guru kemudian menyuruh dua orang peserta didik untuk duduk berpasangan dan saling berdiskusi membahas materi yang disampaikan oleh guru. Pasangan peserta didik saling mengkoreksi kesalahan masing-masing dan menjelaskan hasil diskusinya di kelas. Guru menambah materi yang belum dikuasai peserta didik berdasarkan penyajian hasil diskusi.

Setelah siswa mempelajari materi yang diberikan guru selama kegiatan belajar, maka untuk mengukur sejauhmana kemampuan siswa tersebut dilakukanlah tes sebagai hasil belajar dari siswa. Menurut Dimyati dan Mudjiono (2013, p.200) bahwa "Hasil belajar merupakan proses untuk menentukan nilai belajar siswa melalui kegiatan penilaian dan pengukuran hasil belajar". Kegiatan penilaian tersebut bisa dilakukan pada kegiatan inti dalam pembelajaran sebagai lembar kerja siswa (LKS) atau kegiatan akhir berupa evaluasi, disesuaikan dengan materi.

Kemudian diperjelas oleh Sudjana (2008, p.22) bahwa "hasil belajar adalah kemampuan-kemampuan yang dimiliki siswa setelah ia menerima pengalaman belajarnya". Kemampuan tersebut diukur melalui penilaian, sehingga akan terlihat sejauhmana tujuan yang telah ditetapkan itu tercapai atau tidak. Maka dari itu penilaian berfungsi sebagai alat untuk mengetahui keberhasilan proses dan hasil belajar siswa.

Sebagaimana yang kita ketahui bahwa IPS lebih mengarah pada kegiatan sosial di masyarakat yang di dalamnya terdapat berbagai macam perbedaan dari manusia itu sendiri. Menurut Supriatna (2009, p.3) "IPS merujuk pada kajian yang memusatkan perhatiannya pada aktivitas kehidupan manusia”.Aktivitas yang dimaksudkan merupakan segala hal yang dilakukan manusia dalam kehidupan 
sehari-hari, dimana mereka berperan sebagai masyarakat dan bersosialisasi dengan masyarakat lainnya. Kemudian diperjelas dalam Kurikulum KTSP (dalam BSNP, 2006, p.175) yang menyatakan bahwa:

IPS mengkaji seperangkat peristiwa dan fakta, konsep dan generalisasi yang berkaitan dengan isu sosial, melalui mata pelajaran IPS peserta diarahkan untuk menjadi warga negara Indonesia yang demokratis dan bertanggung jawab serta warga dunia yang cinta damai.

IPS diajarkan di sekolah dengan tujuan untuk membantu siswa menjadi pribadi yang lebih baik dalam segala hal, baik untuk dirinya sendiri maupun untuk orang lain, dan membantu siswa dalam mempersiapkan dirinya untuk menjadi warga negara yang baik dan menjunjung tinggi nilai demokrasi.

\section{B. METODOLOGI PENELITIAN}

Penelitian ini merupakan penelitian tindakan kelas (classroom action research). Penelitian tindakan dalam bidang pendidikan yang dilaksanakan dalam kawasan kelas dengan tujuan untuk memperbaiki dan meningkatkan kualitas pembelajaran. Secara singkat PTK dapat didefinisikan sebagai suatu bentuk penelaahan penelitian yang bersifat reflektif dengan melakukan tindakan-tindakan tertentu agar dapat memperbaiki dan meningkatkan praktik praktik pembelajaran di kelas secara lebih professional (Basrowi, Suwandi, 2008, p.28).

Dalam pelaksanaannya, penelitian tindakan kelas ini menggunakan model Kurt Lewin yang menyatakan bahwa dalam satu siklus terdiri dari empat langkah pokok yaitu : (1) perencanaan (planning), (2) aksi atau tindakan (acting), (3) observasi (observing), dan (4) refleksi (reflecting). Secara keseluruhan, empat tahapan dalam PTK tersebut membentuk suatu siklus PTK yang digambarkan dalam bentuk spiral.

Penelitian tindakan kelas ini dilaksanakan di SMP Negeri 2 Palembang. Guru sebagai guru mata pelajaran IPS di sekolah ini. Guru akan memecahkan masalah rendahnya hasil belajar pembelajaran mata pelajaran IPS di SMP Negeri 2 Palembang. Waktu penelitian ini dilaksanakan pada bulan Agustus 2019 s.d Oktober 2019 tahun pelajaran 2019/2020, pokok bahasan yang disampaikan 
Penerapan Model Pembelajaran....(Nurma)

adalah " Memahami kehidupan sosial manusia". Subjek yang dimaksud tindakan dalam penelitian ini adalah peserta didik kelas VII.8 SMP Negeri 2 Palembang yang berjumlah 32 peserta didik, sedangkan partisipan yang terlibat dalam penelitian ini adalah guru mata pelajaran dan teman sejawat lainnya.

\section{HASIL PENELITIAN DAN PEMBAHASAN}

\section{Hasil Siklus I}

Pelaksanaan tindakan melalui model pembelajaran kooperatif tipe Think Pair share pada siklus I dibagi menjadi 2 pertemuan, yaitu pertemuan 1 dan 2 . Siklus I pertemuan 1 dilaksanakan pada hari Selasa, tanggal 20 Agustus 2019 dan pertemuan 2 pada hari Kamis, tanggal 22 Agustus 2019 di kelas VII.8 SMP Negeri 2 Palembang dengan alokasi waktu 2x35 menit atau sama dengan 2 jam pelajaran. Pelaksanaan pembelajaran mengacu pada rencana pembelajaran yang telah disusun oleh peneliti, yaitu pokok bahasan menjelaskan interaksi sebagai proses sosial pada siklus I.

Pembelajaran dimulai dengan siswa berdo"e a bersama yang dipimpin oleh ketua kelas, siswa memberikan salam kepada guru. Guru terlebih dahulu menegur siswa yang pada saat berdo ${ }^{e} a$ terlihat masih berbicara dan bermain dengan teman sebelum mempresensi kehadiran siswa. Guru memberikan pesan kepada siswa agar pada saat berdo ${ }^{e e}$ a lebih baik tidak berbicara sendiri.

Guru menyampaikan inti materi dan kompetensi yang akan dicapai. Peserta didik diminta untuk berpikir tentang materi yang disampaikan guru .Peserta didik diminta berpasangan dengan teman sebelahnya (satu kelompok 2 orang) dan mengutarakan persepsi masing-masing tentang apa yang telah disampaikan oleh guru .Guru memimpin diskusi kecil, tiap kelompok mengemukakan hasil diskusinya .Guru melengkapi materi yang masih belum dipahami siswa dan menegaskan kembali pokok permasalahan yang harus dipahami.

Kegiatan akhir siklus I, guru menjelaskan rangkuman materi secara singkat dan meminta siswa untuk mengerjakan soal latihan yang ada di dalam Buku agar siswa lebih memahami materi. Guru memberikan motivasi kepada siswa untuk 
terus belajar dan memberikan informasi tentang materi yang akan dipelajari pada pertemuan berikutnya. Guru mengakhiri pelajaran dengan meminta siswa untuk mengucapkan salam.

Pengamatan (observasi) dilakukan bersamaan dengan kegiatan pelaksanaan pembelajaran atau tindakan serta dilakukan dengan menggunakan lembar observasi yang telah dipersiapkan. Kegiatan adalah kegiatan pengamatan terhadap aktivitas guru dan aktivitas siswa dalam pembelajaran. Kegiatan observasi dilakukan oleh observer bertugas untuk mengamati aktivitas siswa dari awal sampai akhir pembelajaran.

Pencapaian hasil belajar siswa pada siklus I dapat dilihat dari hasil ketuntasan belajar siswa yang diperoleh pada siklus I, hasil ketuntasan belajar siswa dapat ditunjukan pada tabel 1 di bawah ini:

Tabel 1 Hasil Belajar Siklus I

\begin{tabular}{|ll|}
\hline Jumlah Nilai & $=2140$ \\
\hline Jumlah Nilai Maksimal ideal & $=3200$ \\
\hline Rata-rata Nilai Tercapai & $=66.88$ \\
\hline Jumlah siswa yang belum tuntas & $=14$ \\
\hline Jumlah siswa yang tuntas & $=18$ \\
\hline Persentase Belum tuntas & $=43.75$ \\
\hline Persentase ketuntasan & $=56.25$ \\
\hline Klasikal & $=$ Belum Tuntas \\
\hline
\end{tabular}

Berdasarkan tabel di atas bahwa rekapitulasi hasil belajar siswa pada mata pelajaran IPS materi mendiskripsikan interaksi sebagai proses sosial yang dilaksanakan pada siklus I, diperoleh nilai rata-rata sebesar 66,88. Jumlah siswa yang tuntas adalah 18 siswa dari 32 jumlah seluruh siswa. Sedangkan siswa yang belum tuntas adalah 14 siswa dari 32 jumlah seluruh siswa. Persentase ketuntasan yang dicapai pada siklus I adalah 56,25\%. Berdasarkan data yang diperoleh dapat disimpulkan bahwa 14 siswa masih mengalami kesulitan dalam menyelesaikan soal evaluasi. Siswa yang belum tuntas, mendapatkan nilai yang kurang baik dan belum mencapai batas ketuntasan. 
Penerapan Model Pembelajaran ....(Nurma)

Refleksi diadakan terhadap hasil tindakan, yang digunakan untuk mengetahui kelebihan dan kekurangan selama proses pelaksanaan tindakan dalam siklus I. Hasil tindakan siklus I dengan hasil sebagai berikut: Berdasarkan hasil evaluasi siklus I diperoleh nilai rata-rata 66,88 dengan ketuntasan belajar 56,25\%. Upaya meningkatkan hasil belajar perlu dilakukan agar ketuntasan hasil belajar terpenuhi $85 \%$ dari jumlah siswa.

\section{Siklus II}

Pelaksanaan tindakan melalui model pembelajaran kooperatif tipe Think Pair share pada siklus II dibagi menjadi 2 pertemuan, yaitu pertemuan 1 dan 2 . Siklus II pertemuan 1 dilaksanakan pada hari Selasa, tanggal 3 September 2019 dan pertemuan 2 pada hari Kamis, tanggal 5 September 2019 di kelas VII.8 SMP Negeri 2 Palembang dengan alokasi waktu 2x35 menit atau sama dengan 2 jam pelajaran. Pelaksanaan pembelajaran mengacu pada rencana pembelajaran yang telah disusun.

Pembelajaran dimulai dengan siswa berdoa bersama yang dipimpin oleh ketua kelas, siswa memberikan salam kepada guru. Siswa terlihat khusyu dalam berdoa dan tidak ada yang bermain ataupun berbicara dengan temannya. Guru meminta siswa untuk mengeluarakan buku pelajaran yang akan di bahas.

Guru menyampaikan inti materi dan kompetensi yang akan dicapai. Peserta didik diminta untuk berpikir tentang materi yang disampaikan guru. Peserta didik diminta berpasangan dengan teman sebelahnya (satu kelompok 2 orang) dan mengutarakan persepsi masing-masing tentang apa yang telah disampaikan oleh guru . Guru memimpin pleno atau diskusi kecil, tiap kelompok mengemukakan hasil diskusinya. Guru melengkapi materi yang masih belum dipahami siswa dan menegaskan kembali pokok permasalahan yang harus dipahami

Kegiatan akhir siklus II, guru menjelaskan rangkuman materi secara singkat dan meminta siswa untuk mengerjakan soal latihan yang ada di dalam buku latihan sebagai tugas rumah (PR) agar siswa lebih memahami materi. Guru memberikan motivasi kepada siswa untuk terus belajar dan memberikan informasi tentang materi yang akan dipelajari pada pertemuan berikutnya. Guru mengakhiri 
pelajaran dengan meminta siswa untuk membaca hamdalah "Alhamdulillah" dan mengucapkan salam.

Pengamatan (observasi) dilakukan bersamaan dengan kegiatan pelaksanaan pembelajaran atau tindakan serta dilakukan dengan menggunakan lembar observasi yang telah dipersiapkan. Kegiatan observasi adalah kegiatan pengamatan terhadap aktivitas guru dan aktivitas siswa dalam pembelajaran. Kegiatan observasi dilakukan oleh observer bertugas untuk mengamati aktivitas siswa dalam mengikuti pembelajaran. Observer I memberikan penilaian pada aktivitas siswa dengan mengacu pada lembar observasi aktivitas siswa. Aspek yang diamati dari observasi pada siklus III diantaranya sebagai berikut:

Pencapaian hasil belajar siswa pada siklus II dapat dilihat dari hasil ketuntasan belajar siswa yang diperoleh pada siklus II, hasil ketuntasan belajar siswa dapat ditunjukan pada tabel 2 di bawah ini:

Tabel 2 Hasil Belajar Siswa Siklus II

\begin{tabular}{|ll|}
\hline Jumlah Nilai & $=\mathbf{2 4 9 5}$ \\
\hline Jumlah Nilai Maksimal ideal & $=\mathbf{3 2 0 0}$ \\
\hline Rata-rata Nilai Tercapai & $=\mathbf{7 7 . 9 7}$ \\
\hline $\begin{array}{l}\text { Jumlah siswa yang belum } \\
\text { tuntas }\end{array}$ & $=\mathbf{3}$ \\
\hline Jumlah siswa yang tuntas & $=\mathbf{2 9}$ \\
\hline $\begin{array}{l}\text { Persentase Belum } \\
\text { tuntas }\end{array}$ & $=\mathbf{9 . 3 8}$ \\
\hline Persentase ketuntasan & $=\mathbf{9 0 . 6 3}$ \\
\hline Klasikal & $=$ Tuntas \\
\hline
\end{tabular}

Berdasarkan tabel 2 rekapitulasi hasil belajar siswa pada mata pelajaran IPS materi mendiskripsikan sosialisasi sebagai proses pembentukan kepribadian yang dilaksanakan pada siklus II, diperoleh nilai rata-rata sebesar 77,97. Siswa yang tuntas adalah 29 siswa dari 32 jumlah seluruh siswa. Siswa yang belum tuntas adalah 3 siswa dari 32 jumlah seluruh siswa. Persentase ketuntasan yang dicapai pada siklus II adalah 90,63\%. Berdasarkan data tersebut maka dapat diketahui bahwa ketuntasan belajar siswa meningkat dan sudah mencapai Kriteria Ketuntasan Minimum (KKM) yang ditentukan di SMP Negeri 2 Palembang yaitu 70 dengan prosentase ketuntasan prestasi belajar mencapai 90,63\%. 
Berdasarkan hasil penelitian terhadap sikap kerja keras dan hasil belajar siswa yang telah dilakukan pada siklus I dan II sudah mengalami peningkatan dan telah memenuhi indikator keberhasilan dalam penelitian tindakan kelas. Penelitian ini dianggap cukup dan dianggap berhasil karena dapat meningkatkan sikap kerja keras siswa menjadi sangat baik dan telah mencapai prestasi belajar dengan ketuntasan belajar sebesar 90,63\% pada siklus II.

\section{PEMBAHASAN}

Pembahasan pada penelitian tindakan kelas ini didasarkan pada hasil penelitian mulai dari siklus I sampai dengan siklus II. Pembahasan pada hasil penelitian dapat dijelaskan sebagai berikut. Nilai hasil belajar siswa pada mata pelajaran IPS materi mendiskripsikan interaksi sebagai proses sosial diperoleh dari hasil soal evaluasi yang dilaksanakan pada pertemuan setiap akhir siklus.

Hasil belajar siswa meningkat saat siswa melakukan model pembelajaran kooperatif tipe Think Pair share, ditunjukkan dengan setiap siswa mengerjakan soal-soal IPS. Siswa mengerjakan soal dengan cepat dan bersaing dengan kelompok yang lain, karena untuk memenangkan permainan balok pecahan harus sesuai dengan alur yang telah ditentukan oleh guru. Siswa yang merasa kesulitan dalam mengerjakan soal yang ada di dalam mendiskripsikan interaksi sebagai proses sosial dapat berdiskusi dengan kelompoknya. Rekapitulasi hasil belajar siswa pada mata pelajaran IPS materi mendiskripsikan interaksi sebagai proses sosial dapat dilihat pada tabel berikut:

Tabel 3 Peningkatan hasil Belajar Siswa

\begin{tabular}{|l|l|l|l|}
\hline $\begin{array}{l}\text { Proses } \\
\text { Pembelajaran }\end{array}$ & $\begin{array}{l}\text { Persentase } \\
\text { Ketuntasan }\end{array}$ & $\begin{array}{l}\text { Jumlah } \\
\text { Ketuntasan }\end{array}$ & $\begin{array}{l}\text { Nilai Rata } \\
\text { Rata }\end{array}$ \\
\hline Pra Siklus & 34.38 & 11 & 62.34 \\
\hline Siklus I & 56.25 & 18 & 66.88 \\
\hline Siklus II & 90.63 & 29 & 77.97 \\
\hline
\end{tabular}


Berdasarkan tabel 4.7 ditunjukkan adanya peningkatan hasil belajar siswa kelas VII.8 SMP Negeri 2 Palembang pada setiap siklus. Data di atas disajikan dalam grafik 1 di bawah ini :

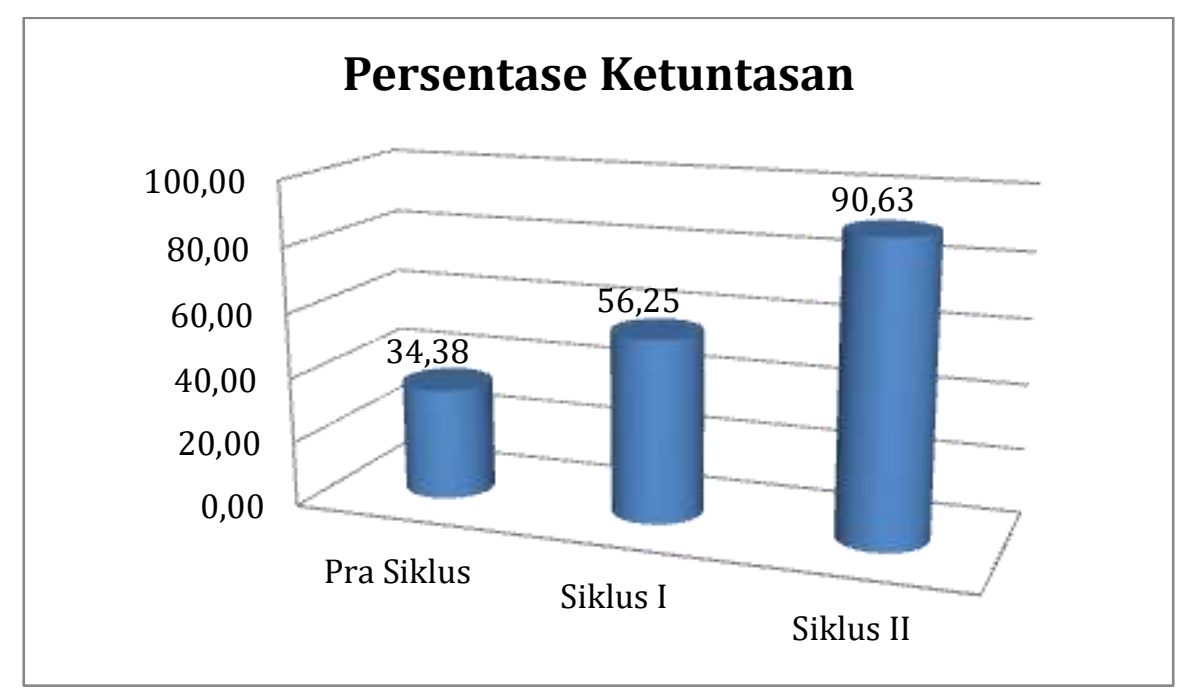

\section{Grafik1 Peningkatan hasil Belajar Siswa}

Berdasarkan tabel 3 dan grafik 1 hasil belajar siswa kelas VII.8 SMP Negeri 2 Palembang di atas, dapat dilihat bahwa ada peningkatan hasil belajar pada setiap siklus. Tercapainya hasil belajar siswa berdasarkan indikator keberhasilan yaitu $85 \%$ terjadi pada siklus II. Rata-rata nilai pada siklus I sebesar 66,88, pada siklus II sebesar 77,97. Ketuntasan belajar pada siklus I sebesar $56,25 \%$, pada siklus II sebesar 90,63 \% dengan kriteria Baik. Berdasarkan hasil observasi, peningkatan hasil belajar siswa dipengaruhi oleh faktor model pembelajaran yang digunakan oleh guru yaitu dengan menggunakan model pembelajaran kooperatif tipe Think Pair share.

Berdasarkan data tersebut dapat disimpulkan bahwa melalui model pembelajaran kooperatif tipe Think Pair share. dapat meningkatkan hasil belajar siswa pada ma ta pelajaran IPS materi mendiskripsikan interaksi sebagai proses sosial. Hal ini ditunjukkan dengan hasil belajar siswa yang telah mencapai indikator keberhasilan yaitu lebih dari $85 \%$ dari jumlah siswa. 
Penerapan Model Pembelajaran....(Nurma)

\section{SIMPULAN}

Berdasarkan hasil penelitian tindakan kelas yang dilakukan selama dua siklus dalam upaya meningkatkan hasil belajar IPS melalui model pembelajaran kooperatif tipe Think Pair share dengan di kelas VII.8 SMP Negeri 2 Palembang, maka diperoleh simpulan bahwa model pembelajaran kooperatif tipe Think Pair share dapat meningkatkan hasil belajar siswa kelas VII.8 SMP Negeri 2 Palembang. Pada siklus I didapatkan skor rata-rata sebesar 66.88 dan siklus II sebesar 77.97.

\section{DAFTAR PUSTAKA}

Basrowi, Suwandi, (2008). Prosedur Penelitian Tindakan Kelas. Anggota IKAPI: Ghalia Indonesia

Dimyati dan Mudjiono. (2013). Belajar dan Pembelajaran. Jakarta: Rineka Cipta Lie, Anita. (2005). Cooperatif Learning. Jakarta: Gramedia.

Mulyatiningsih, E. (2011). Metode Penelitian Terapan Bidang Pendidikan. Yogyakarta: Alfabeta.

Solihatin, Etin dan Raharjo. (2008). Cooperative Learning Analisis Model Pembelajaran IPS. Jakarta: Bumi Aksara.

Somantri, M. N. (2001). Menggagas Pembaharuan Pendidikan IPS. Bandung: PT Remaja Posdakarya

Sudjana, N.. (2008). Dasar-dasar Proses Belajar Mengajar. Bandung: Sinar Baru Algensindo.

Sugiyanto. (2010). Model-model Pembelajaran Inovatif. Surakarta: Yuma Pustaka

Supriatna, D. (2009). Pengenalan Media Pembelajaran, Pusat Pengembangan Dan Pemberdayaan Pendidik Dan Tenaga Kependidikan Taman Kanak Kanak Dan Pendidikan Luar Biasa. Jakarta

Trianto. (2010). Model Pembelajaran Terpadu Konsep, Strategi, dan Implementasinya dalam KTSP. Jakarta: Bumi Aksara

Trianto. (2011). Model-Model Pembelajaran Inovatif Berorientasi Konstruktivitis. Jakarta: Prestasi Pustaka. 